Review

\title{
Biomarkers for Basal-like Breast Cancer
}

\section{Jennifer R. Choo and Torsten O. Nielsen *}

Department of Pathology and Laboratory Medicine, University of British Columbia, Vancouver, Canada; E-Mail: jennchoo@interchange.ubc.ca

* Author to whom correspondence should be addressed; E-Mail: torsten @interchange.ubc.ca; Tel.: +1-604-875-4111 ext. 66768; Fax: +1-604-875-4497.

Received: 19 March 2010; in revised form: 11 May 2010 / Accepted: 19 May 2010 /

Published: 28 May 2010

\begin{abstract}
Initially recognized through microarray-based gene expression profiling, basallike breast cancer, for which we lack effective targeted therapies, is an aggressive form of carcinoma with a predilection for younger women. With some success, immunohistochemical studies have attempted to reproduce the expression profile classification of breast cancer through identification of subtype-specific biomarkers. This review aims to present an in depth summary and analysis of the current status of basal-like breast cancer biomarker research. While a number of biomarkers show promise for future clinical application, the next logical step is a comprehensive investigation of all biomarkers against a gene expression profile gold standard for breast cancer subtype assignment.
\end{abstract}

Keywords: breast cancer; basal-like; biomarkers; intrinsic subtype; immunohistochemistry; triple-negative; basaloid; expression profile

\section{Introduction}

Gene expression profiling has enabled the classification of breast cancers into intrinsic molecular subtypes with diverse clinicopathologic features [1-3]. Representing $\sim 15 \%$ of these biologically and clinically distinct forms of breast cancer [4-6], basal-like carcinomas are of particular interest to clinicians and researchers due to their characteristically poor prognosis and resistance to existing molecularly-targeted treatment modalities, such as endocrine therapy (e.g., tamoxifen and aromatase inhibitors) for hormone receptor-positive disease or trastuzumab for human epidermal growth factor 
receptor-2 (HER2)-positive disease, leaving cytotoxic chemotherapy as the principal systemic treatment [7-10]. Furthermore, younger women have a greater tendency to be afflicted by this aggressive subtype [11-13]. These clinically defining attributes of most basal-like carcinomas illustrate that, while remarkable strides are being made in our understanding of both molecular and genetic mechanisms of breast cancer, characterization of the basal-like subtype is a critical focus for clinical translation as both new diagnostics and treatments are needed.

Basal-like breast carcinomas exhibit a certain degree of heterogeneity in their expression profile, morphology, immunophenotype, prognosis and treatment response. Basal-like gene expression profiles and biomarker expression are seen not only in typical high grade infiltrating ductal carcinomas, but also in metaplastic [14], secretory [15], medullary [16] and prognostically favorable adenoid cystic carcinomas [17]. Nevertheless, Weigelt et al. [18] recently provided strong support for the concept of basal-like breast cancer by illustrating that it is the intrinsic subtype most consistently identifiable by gene expression profile analysis. Multiple studies using different platforms and methodologies have revealed that basal-like breast carcinomas are generally characterized by negative expression of hormone receptors and related genes, as well as positive expression of a set of genes typically associated with basal epithelial cells, such as basal cytokeratins, P-cadherin, $\beta 4$ integrin and nestin, in addition to several genes involved in cellular proliferation [1,2,19]. Given such consistencies in gene expression patterns, Stingl and Caldas [20] proposed that molecular characterization of breast cancers may provide insight into their cellular origins. However, the histogenesis of basal-like breast carcinomas is a controversial topic with some researchers believing these cancers develop from a multi-potential early precursor cell and others supporting the theory that such breast carcinomas arise from partially-committed luminal progenitor cells [21-23]. Simple studies on the preferential expression of basal versus luminal cytokeratins have been unable to provide sufficient support for either hypothesis [24], leading to extensive research efforts currently underway to find an answer.

As histology is not consistently distinctive, and large scale expression profiling is not readily applied in a clinical setting, the search for clinically-practical cancer biomarkers that act as surrogate measurements of disease states is rapidly expanding in support of the paradigm shift towards more personalized medicine in this post-genomic era [25]. From improving the accuracy of diagnosis or risk assessment (via prognostic biomarkers) to guiding selection of optimal therapeutic interventions (via predictive biomarkers) [8,26-28], the potential clinical applications of these biological indicators are widely recognized in breast cancer research as having the potential to revolutionize patient management. Biomarkers for basal-like breast cancer are a subject of active and intense investigation for accurate diagnosis and therapeutic targets. The aim of this review is to evaluate our current state of knowledge on basal-like biomarkers as well as provide a critical survey of candidate biomarkers of basal-like breast cancer drawn from literature, followed by recommendations for future research directions. Particular emphasis is placed on immunohistochemical biomarkers confirmed on clinical biopsy and excision samples, as opposed to breast cancer cell lines, explanted or animal models.

\section{Biomarker Panels for Basal-like Breast Cancer}

Tumor biomarkers can encompass a range of molecules from nucleic acids to metabolites. However, protein biomarkers convert most readily into targeted therapies (as most pharmaceuticals tend to target proteins) and clinical diagnostic assays using standard existing platforms [28,29]. For 
instance, practical and clinically-accessible immunohistochemical techniques used routinely for breast cancer patient management are predominantly applicable to protein biomarkers. Despite semiquantitative results and susceptibility to both inter-observer and technical variation-short comings which can be remedied to some extent through sufficient training and implementation of stringent protocols-immunohistochemistry is suited for application on formalin-fixed paraffin-embedded samples and also provides the unique advantage of simultaneous morphological analysis. In fact, few published reports on basal-like breast cancer have used a gene expression profile gold standard, opting instead to use immunohistochemistry-based methodologies while investigating this subtype primarily due to cost, but also to avoid the complex sample preparation and data analysis processes [5,30].

Further establishing immunohistochemistry as a cornerstone in breast cancer research, tissue microarrays enable highly efficient processing of hundreds to thousands of archival tumor specimens at one time with even more significant cost savings [31,32]. Facilitated by this relatively new technology, biomarker development has excelled to the point where prospectively-designed re-analyses of existing material (such as samples from completed clinical trials with extensive follow-up), sometimes termed 'retrospective-prospective studies', are beginning to generate clinically meaningful data about predictive biomarkers, and have the potential to change medical practice more quickly than new clinical trials [31,33-35]. Even so, finding a single biomarker that fulfills all requirements necessary to be deemed applicable in routine analysis has proven to be extremely difficult for basal-like carcinomas. More realistically, panels of breast cancer biomarkers can be designed in anticipation of phenotypic heterogeneity, and some have emerged with sufficient sensitivity and specificity for use in prognostication or prediction of treatment response in the clinical setting.

\subsection{Current Examples: Immunohistochemical Definitions of Basal-like Breast Cancer}

Immunohistochemical analysis of HER2 as well as estrogen and progesterone receptors (ER and $\mathrm{PR}$, respectively) is used for predictive purposes in routine breast cancer patient management. Lack of expression of all three of these biomarkers predicts non-response to available endocrine (tamoxifen, aromatase inhibitors) and anti-HER2 (trastuzumab) targeted therapies, and has become known as a triple-negative phenotype (TNP). With approximately $70-90 \%$ of triple-negatives revealed to be basal-like breast carcinomas [36,37], TNP has been frequently used as a surrogate for the basal-like subtype. However, despite considerable overlap in behavioral/biological characteristics, several studies have shown that triple-negative and basal-like breast tumors are not synonymous, differing in prognosis and possibly in chemotherapeutic sensitivity [12,38-41]. Furthermore, an all-negative definition has a high propensity to mis-assign tumor classifications when biomarkers are negative for technical reasons. This and similar lines of evidence have prompted most researchers to acknowledge a distinction between TNP and basal-like tumors, leading to scrutiny of the validity of the triple-negative definition for basal-like breast cancer $[12,38,42,43]$. The primary reason for the continued use of a TNP category of breast cancers is its simplicity and convenience (based solely on information that can be readily extracted from a patient's chart), and its identification of a specific group of breast cancers for which current targeted therapies are not expected to provide benefit.

Another approach used to identify basal-like breast carcinomas is based on positive expression of basal cytokeratins (CKs) 5, 14 and 17 [6,13,44-46]. Prior to the discovery of the breast cancer intrinsic 
molecular subtypes, a number of studies had confirmed an association between poor prognosis and basal cytokeratin expression [1,47-51]. Subsequent research undertaken in light of the molecular identification of the basal-like subtype has greatly extended our knowledge of the clinical features associated with expression of basal cytokeratins in breast cancer $[6,13,46]$, and these biomarkers have been used alone or incorporated into several immunohistochemical panels for identifying basal-like breast carcinomas. For instance, by comparing gene expression profiles to immunohistochemical results obtained using technically well-established antibodies, Nielsen et al. [5] defined basal-like breast cancer as any staining with CK5/6 or epidermal growth factor receptor (EGFR) antibodies in the context of HER2 and ER negativity (Figure 1). With a reported $76 \%$ sensitivity and $100 \%$ specificity for the basal-like subtype this definition has been widely used, and it has since been modified to incorporate PR-negativity to form a 5-marker immunopanel with greater prognostic value than the TNP definition for basal-like breast cancer [12]. Similarly, Livasy et al. [52] reported that negative expression of ER and HER2 with positive expression of EGFR, CK5/6, CK8/18 and vimentin was the most consistent immunophenotype of basal-like breast tumors. Also, yet another surrogate immunopanel with $78 \%$ sensitivity and $100 \%$ specificity against a gene expression profile gold standard was recently reported by Thike and colleagues [53], consisting of CK14, EGFR and a mixture of high molecular weight basal cytokeratins (using the pan-basal cytokeratin monoclonal antibody 34ßE12).

Figure 1. Immunohistochemical staining of a representative basal-like breast cancer using the definition of Nielsen et al. [5]. The case illustrated is ER negative, HER2 negative, EGFR strong positive and CK5/6 weak positive.

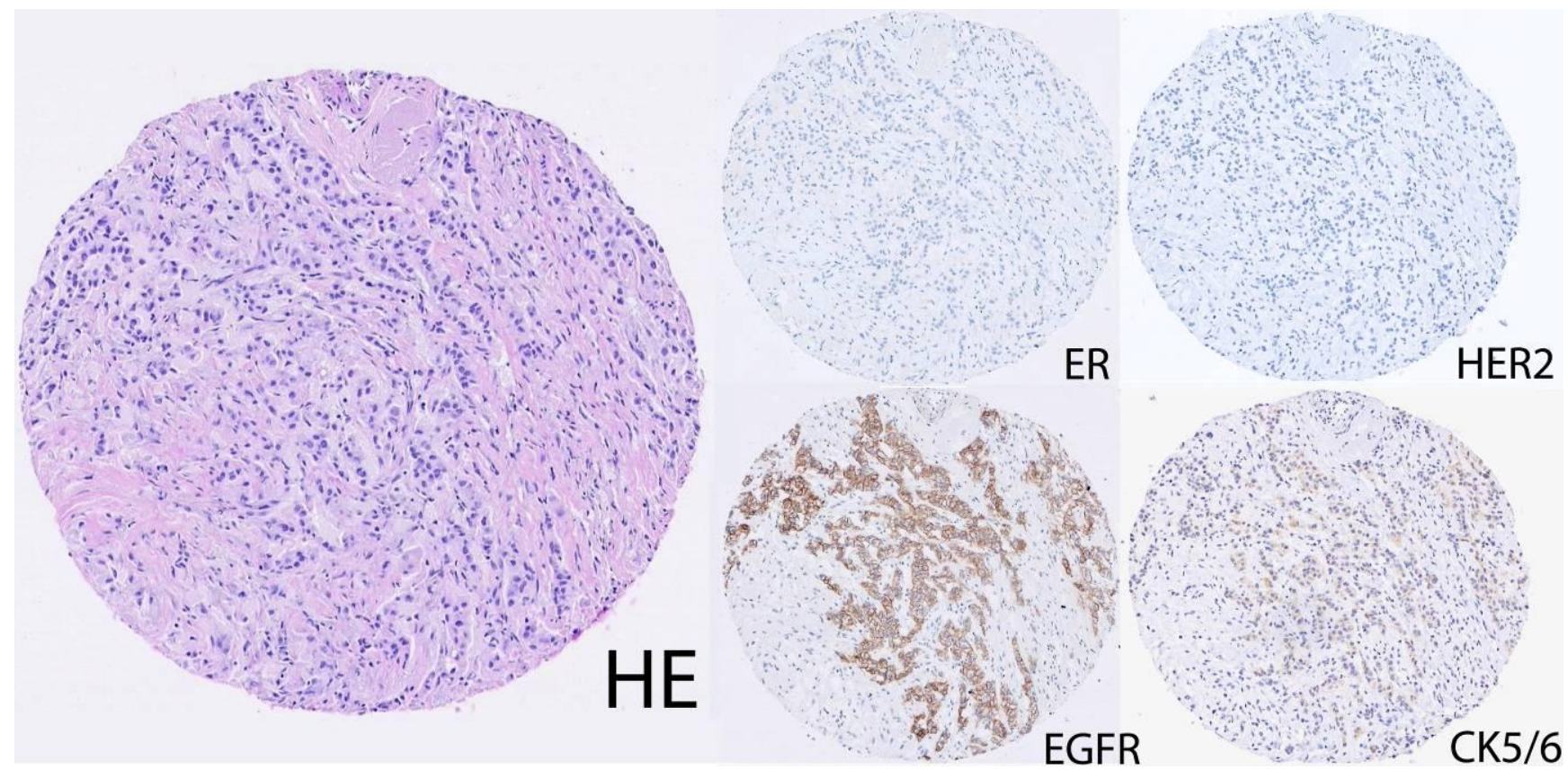

\subsection{Lack of a Consensus}

The seminal paper by Perou and colleagues [1] that first elucidated the molecular portrait of breast cancer is largely responsible for inspiring interest in the basal-like subtype, catalyzing biomarker research for the purpose of recapitulating the gene expression classification as well as characterizing the biological and clinical features of this form of breast cancer. Although expression profiling can be 
considered a gold standard for identification of basal-like breast cancer, whether performed using microarrays or newer sequencing-based approaches such as the PAM50 qRT-PCR assay [54], it is currently not a feasible approach for large-scale application on routine formalin-fixed paraffinembedded clinical samples (required for both retrospective application on large sample cohorts with long term follow-up and prospective application in standard hospital pathology laboratories). For this reason, immunohistochemical surrogates have become an important alternative. Major definitions are negative (i.e., ER/HER2 double- or triple-negative incorporating PR), positive (e.g., purely based on basal cytokeratin expression), or a combination. Unfortunately, variable immunohistochemical definitions have impeded consistency in the interpretation of retrospective studies and confounded proposals for prospective implementation. In general, incorporating additional biomarkers into a panel can increase specificity, at the potential cost of sensitivity. Many biomarkers have been associated with the basal-like phenotype, and those with high sensitivity and/or specificity could improve the performance of immunohistochemical surrogate panels.

\section{Biomarkers Associated with a Basal-like Breast Cancer Phenotype}

In effort to develop clinical tests that more reliably diagnose this aggressive subtype of breast cancer and/or best define an entity that may have predictive value for treatment selection, many studies have been published over the last decade describing additional biomarkers that correlate with a clinical triple-negative phenotype, established immunohistochemical surrogates for basal-like breast cancer, or in some cases a microarray gold standard definition. Ranging from structural proteins to those involved in cellular processes, such as signal transduction and apoptosis, the proposed biomarkers for the basal-like subtype are diverse in class and function.

\subsection{Structural}

Structural proteins reported to have increased expression in basal-like breast carcinomas include basal cytokeratins (CK5/6, CK14 and CK17) [1,13,44,46,47,55], vimentin [52,56-58], fascin [58-60], nestin [61-63] and moesin [64,65]. Such cytoskeletal components are favorable antigens for immunohistochemical detection because of their stable and abundant cellular expression. Specificity can be an issue as these proteins are expressed in many cell types including benign breast epithelial and stromal elements, and so generally must be interpreted in their morphological context by an experienced pathologist. Most are still under investigation and have yet to provide actual clinical utility beyond that initially reported in the original publications, with the exception of basal cytokeratins which are perhaps the oldest and most clinically characterized biomarkers of basal-like breast carcinomas. For instance, Kusinska et al. [66] recently sought to address whether the inclusion of vimentin in an immunopanel consisting of ER, PR, HER2, and basal cytokeratins (CKs 5/6, 14 and 17) would better delineate their basal-like breast cancer definition (i.e., TNP combined with basal cytokeratin positivity) using overall survival as the primary endpoint. In their analysis, it was determined that vimentin did not contribute prognostically to the immunopanel, which somewhat contradicts the results of Livasy et al. [52] mentioned previously while discussing current immunohistochemical definitions of basal-like breast cancer [66]. 
Playing a different type of structural role within the cell, claudins are protein components of tight junctions responsible for maintaining cell polarity and establishing a paracellular barrier that controls the ionic permeability of epithelial tissues [67]. Preferential expression of claudins 1 and 4 has been associated with poor prognosis and basal-like breast cancer [68-70]. Of a related nature (as structural components of plasma membrane caveolae), increased expression of both caveolin 1 and 2 has also been linked to the basal-like subtype [71-74]. A clear resolution of the role of the caveolins as basallike biomarkers is hindered by controversy regarding their cellular distribution in invasive breast cancer, as well as recent evidence indicating a potentially stronger prognostic role for stromal rather than tumor cell expression of caveolin 1 [75,76].

\subsection{Extracellular Interactions \& Signal Transduction}

Cell-cell and cell-extracellular matrix contacts mediate signaling cascades that culminate in diverse molecular responses pivotal to cancer, including angiogenesis, cell division, apoptosis, invasion and metastasis [77]. Some reported basal-like biomarkers are proteins normally secreted into the extracellular matrix, such as osteonectin (also known as SPARC) and osteopontin. These bone matrixassociated factors do not have well-defined primary roles in breast structure [58,78-80]. Osteopontin is a phosphorylated glycoprotein found in all body fluids, but its overexpression in the tumor cells of breast and other cancers has led to its investigation as a potential biomarker and anti-metastatic therapeutic target $[81,82]$. A study by Wang et al. [37] in which mean osteopontin levels were found to be significantly higher in triple-negative relative to non-triple-negative breast carcinomas provides preliminary evidence of a possible association with basal-like breast cancer.

The laminin family of extracellular matrix glycoproteins involved in cellular adhesion has been associated with the basal-like subtype [57]. Specifically, high expression of laminin 5 (more recently referred to as laminin 332) has been observed in a variety of tumors including basal-like breast carcinomas [83,84]. A cell surface interacting partner for most laminins is $\alpha 6 \beta 4$ integrin, which is known to modulate signaling pathways involved in proliferation and survival $[85,86]$. Interestingly, Lu et al. [86] reported that the $\beta 4$ integrin subunit is preferentially expressed in basal-like breast cancer compared to non-basal-like. Other cell surface molecules that are reported to exhibit increased expression in the basal-like subtype include nerve growth factor receptor (NGFR) [87], CD109 [88], placental cadherin (P-cadherin; P-CD) [4,89-91], CD44 [92,93], CD280 (also known as Endo180) [43,94], c-Met [64,95,96] and CD146 (also known as melanoma cell adhesion molecule) $[95,97]$. Illustrating the necessity for standardization of the methods and approaches used for biomarker analysis, contradictory evidence suggesting a breast tumor inhibitory role for CD146 has also been reported [98,99]. As noted by Ouhtit and co-workers [98], one of the original immunohistochemical studies that correlated CD146 overexpression with the basal-like subtype of breast cancer considered normal CD146 endothelial cell staining alone within tumor tissue as a CD146-positive tumor, which undoubtedly influenced the findings of the paper. In spite of this, a recent study by Zabouo et al. [97] confirmed a statistically significant association between CD146 and basal-like versus non-basal-like breast cancer as defined by a gene expression profile gold standard.

A select number of players involved in signal transduction have shown enough promise in both breast and other types of cancer to warrant major efforts in rational drug design. EGFR [5,100-103], c-Kit (also known as CD117) [5,17,102] and vascular endothelial growth factor (VEGF) [104,105] are 
candidate biomarkers of basal-like breast cancer with targeted therapies in development. Examples of possible biology-based therapeutic options available for treatment of basal-like breast cancer include anti-EGFR monoclonal antibodies (cetuximab and panitumumab), EGFR tyrosine kinase inhibitors (gefitinib, erlotinib and lapatinib), imatinib for c-Kit kinase inhibition and bevacizumab for VEGF inhibition [106-110]. Initial trials in breast cancer have been somewhat disappointing with only moderate clinical efficacy; the described biomarkers may not be sufficiently robust to provide predictive value [111-115]. However, the relatively prevalent overexpression of EGFR, c-Kit and VEGF among basal-like and triple-negative breast cancers has maintained hope that current trials underway restricted to these tumor types will maximize the chance of identifying a responsive subgroup of breast cancer and offer more definitive data [104,105,116,117].

\subsection{Transcription, Cell Cycle Regulation and DNA Damage Repair}

While the cell surface components that govern tumor interactions have gained extra attention because they are targeted by several new pharmaceuticals, common downstream signaling effects culminating in transcriptional activation and subsequent dysregulation of a multitude of cellular processes, represent more consistent driving forces of oncogenesis [78,118]. As might be expected, several transcription factors have been demonstrated to be preferentially expressed in basal-like breast cancer including c-Myc [43], Sox2 [56,119], FOXC1 [120,121], FOXC2 [122], E2F-5 [123], YB-1 [103,124,125], p-JNK [126], p63 [2,4,127] and p53 [2,11,128,128]. It is important to note that both overexpression and mutation of p53 are collectively seen in more than $85 \%$ of basal-like breast tumors [130-132]. Given that p53, as the "guardian of the genome", is a critical tumor suppressor protein, its mutation or deletion is commonly observed in many aggressive cancer types [133,134]. With regards to refining the immunohistochemical classification of basal-like breast cancer, the clinical utility of p53 in routine analysis may be limited since the specific location and type of mutation in the protein was recently shown to influence clinical outcome in breast cancer patients [135]. Consequently, while p53 accumulation is considered a classic indicator of its mutation status, the best approach for p53 analysis is likely a more technically-demanding combination of immunohistochemistry and genetic screening techniques as recently illustrated by Manie et al. [129].

Being key players involved in regulation of the cell cycle, biologically plausible reports of p16, Skp2 and cyclin E overexpression in basal-like breast cancer have been made [45,130,136-141]. Interestingly, a tissue microarray study by Voduc and colleagues [138] that investigated the combinatorial overexpression of Skp2 and cyclin E in breast cancer was able to confirm the association with the basal-like subtype and prognostic significance in univariable but not multivariable analysis (taking into account standard clinicopathologic variables, such as patient age, tumor size, tumor grade and nodal status). Such results, possibly attributable to a lack of statistical power, may simply suggest that the combination of Skp2 and cyclin E would be more useful as part of a larger immunopanel [138]. Similarly, Ki67 (involved in rRNA synthesis and other unidentified cellular functions) is an established marker of proliferation associated with the basal-like subtype and poor prognosis [59,142,143]. However, the high Ki67 index characteristic of high grade and ER negative tumors renders it prognostically insignificant within the basal-like subtype of breast cancer [144,145].

Although of controversial value as an immunohistochemical biomarker, the relationship between BRCA1 status and basal-like breast cancer could potentially lead to great progress in the field. 
Deficiency of normal BRCA1-mediated double-stranded DNA repair function predisposes female carriers to early development of ovarian cancer and, more commonly, to a highly aggressive form of breast carcinoma [146]. Relating back to the earlier discussion of p53, a strong correlation between BRCA1-related hereditary breast cancer and the basal-like subtype was initially made based on preferential overexpression of p53 and other phenotypic similarities [19,147]. Furthermore, studies have demonstrated disruption of BRCA1 through epigenetic and other regulatory mechanisms, which may occur in sporadic cases of basal-like or triple-negative breast cancer [148-150]. Several immunohistochemical and gene expression profiling studies have shown that BRCA1-deficient tumors possess many biological and molecular characteristics of basal-like breast cancer $[3,19,79,130,151,152]$. Correspondingly, the manifestation of a basal-like phenotype by BRCA1 inactivation has been shown in breast cancer cells $[153,154]$ and corroborated in animal studies by multiple groups, providing further support for the association between BRCA1 pathway disruption and basal-like breast carcinomas $[155,156]$. Exploitation of this relationship, provides the rationale to target basal-like breast tumors using inhibitors of poly [ADP-ribose] polymerase 1 (PARP1; involved in single-stranded DNA break repair), since it is postulated that pharmaceutical inhibition of PARP1 in combination with the pre-existing DNA repair dysfunction from BRCA1 deficiency underlies a situation of synthetic lethality for tumor cells, yet minimal toxicity to normal cells [146]. Clinical trials of PARP1 inhibitors in BRCA1-related and/or triple-negative breast cancers are currently underway to address this hypothesis [157-159], and preliminary results in ovarian cancer have been promising [160,161].

\subsection{Biomarkers of Miscellaneous Function}

A summary of reported biomarkers of basal-like breast cancer can be found in Table 1, which also includes several proposed biomarkers that did not clearly fall into the above categories. While less well-defined, increased expression of insulin-like growth factor mRNA binding protein 3 (IMP3) [162], aldehyde dehydrogenase 1 (ALDH1) [163,164], aquaporin 1 (AQP1) [165], basal/myoepithelial markers belonging to the $\mathrm{S} 100$ family of proteins (A2, A8 and A9) $[80,83,86,166,167]$, organic anion transporting polypeptide 2 (OATP2) [10], phosphohistone H3 [168] and the multidrug-resistance pump P-glycoprotein [169] have each been associated with basal-like and/or triple-negative breast cancers. In addition, the recently observed overexpression of carbonic anhydrase IX (CAIX; CA9) in basal-like carcinomas supports what has long been suspected, that tumors of this subtype activate a hypoxic response to survive under conditions of rapid and aggressive growth [40,170]. As noted by Lancashire et al. [170], the focal expression of CAIX (and any marker with a similar expression pattern) requires immunohistochemical assessment on whole tissue sections as opposed to tissue microarray cores for optimal detection. Finally, fatty acid binding protein 7 (FABP7) [10,43,171] and $\alpha \mathrm{B}$-crystallin [172,173] have preferentially higher expression in the basal-like subtype at both the protein and DNA level making them prime candidates for further investigation as biomarkers of basal-like breast cancer [1,2,19]. 
Table 1. Candidate immunohistochemical biomarkers of basal-like breast cancer.

\begin{tabular}{|c|c|c|c|c|c|}
\hline Biomarker & $\begin{array}{c}\text { Experiment } \\
\text { Format } \\
\end{array}$ & $\begin{array}{l}\text { Basal-like } \\
\text { Definition }\end{array}$ & $\begin{array}{c}\text { Frequency Among } \\
\text { Basal-like (\%) } \\
\end{array}$ & $\begin{array}{l}\text { Frequency Among } \\
\text { Non-basal-like (\%) }\end{array}$ & $\begin{array}{l}\text { Literature } \\
\text { References }\end{array}$ \\
\hline Vimentin & TMA & Combined & $21 / 27(78)$ & $30 / 194(16)$ & [57] \\
\hline Fascin & TMA & Combined & $14 / 26(54)$ & 43/198 (22) & [59] \\
\hline \multirow[t]{3}{*}{ Nestin } & Whole sections & TNP & $12 / 21(57)$ & $12 / 129(9)$ & {$[61]$} \\
\hline & Whole sections & TNP & $14 / 16(88)$ & 0/32 (0) & {$[62]$} \\
\hline & TMA & Combined & $15 / 22(68)$ & $3 / 143(2)$ & {$[63]$} \\
\hline Moesin* & TMA & Combined & $23 / 28(82)$ & $14 / 64(22)$ & [65] \\
\hline Claudin 1 & TMA & Combined & $11 / 18(61)$ & ND & {$[68]$} \\
\hline Claudin 4 & TMA & Combined & $34 / 38(90)$ & $42 / 66(64)$ & [69] \\
\hline \multirow[t]{3}{*}{ Caveolin 1} & TMA & Combined & $17 / 53(32)$ & $25 / 314(8)$ & {$[71]$} \\
\hline & TMA & Combined & $11 / 53(21)$ & $10 / 435(2)$ & {$[72]$} \\
\hline & Whole sections & Combined & $21 / 30(70)$ & $1 / 202(0)$ & {$[73]$} \\
\hline \multirow[t]{2}{*}{ Caveolin 2* } & TMA & Combined & $10 / 50(20)$ & $5 / 270(2)$ & {$[71]$} \\
\hline & TMA & Combined & $11 / 28(39)$ & $1 / 173(0)$ & [74] \\
\hline Osteopontin* & Whole sections & TNP & ND & ND & {$[37]$} \\
\hline Laminin & TMA & Combined & $11 / 26(42)$ & 28/193 (15) & [57] \\
\hline B4 Integrin & Whole & TNP & $15 / 27(56)$ & $18 / 71(25)$ & {$[86]$} \\
\hline NGFR** & TMA & Combined & $10 / 33(30)$ & $1 / 190(0)$ & [87] \\
\hline CD109 & Whole sections & TNP & $18 / 30(60)$ & 0/53 (0) & {$[88]$} \\
\hline \multirow{2}{*}{ P-cadherin } & TMA & Combined & $10 / 12(83)$ & $34 / 128(27)$ & {$[4]$} \\
\hline & Whole sections & Combined & $6 / 8(75)$ & 13/68 (19) & {$[90]$} \\
\hline CD44 (high) & TMA & Combined & $20 / 23(87)$ & $61 / 141(43)$ & [93] \\
\hline OATP2 & TMA & Basal CK & 23/161 (14) & 20/394 (5) & {$[10]$} \\
\hline \multirow[t]{2}{*}{ CD280* } & TMA & Combined & $6 / 28(21)$ & $2 / 175$ & {$[94]$} \\
\hline & TMA & Combined & $9 / 66(14)$ & $11 / 302(4)$ & {$[94]$} \\
\hline CD146 & TMA & TNP & $25 / 76(33)$ & $13 / 425(0)$ & {$[97]$} \\
\hline \multirow[t]{2}{*}{ EGFR* } & TMA & GEP & $41 / 93(44)$ & $41 / 521(8)$ & [5] \\
\hline & Whole sections & TNP & $163 / 284(57)$ & ND & {$[101]$} \\
\hline c-Kit & TMA & Basal CK & $32 / 102(31)$ & $67 / 605(11)$ & [5] \\
\hline VEGF & Whole sections & Basal CK & $15 / 54(28)$ & 4/46 (9) & {$[105]$} \\
\hline Sox2 & TMA & Combined & $13 / 30(43)$ & 16/147 (11) & [119] \\
\hline FOXC1 & TMA & Combined & ND & ND & {$[120,121]$} \\
\hline FOXC2 & TMA & NS & $8 / 18(44)$ & 4/99 (4) & [122] \\
\hline \multirow[t]{2}{*}{ E2F-5 } & Whole sections & TNP & $14 / 27(52)$ & $5 / 30(17)$ & {$[123]$} \\
\hline & Whole sections & Combined & $14 / 25(56)$ & $5 / 32(16)$ & {$[123]$} \\
\hline YB-1 & TMA & TNP & $27 / 37(73)$ & ND & {$[103]$} \\
\hline p-JNK & Whole sections & Combined & $16 / 25(64)$ & $59 / 134(44)$ & {$[126]$} \\
\hline \multirow[t]{2}{*}{ p63 } & TMA & Combined & $6 / 11(56)$ & 24/137 (18) & [4] \\
\hline & Whole sections & Basal CK & $13 / 19(68)$ & $3 / 83(4)$ & [127] \\
\hline \multirow[t]{4}{*}{ p53 } & Whole sections & Basal CK & $7 / 19(37)$ & $28 / 83(34)$ & {$[127]$} \\
\hline & TMA & TNP & $13 / 32(41)$ & 44/103 (43) & {$[128]$} \\
\hline & Whole sections & Basal CK & $32 / 95$ (34) & 27/151 (18) & {$[130]$} \\
\hline & Whole sections & Basal CK & $25 / 49(51)$ & $100 / 278(36)$ & [169] \\
\hline
\end{tabular}


Table 1. Cont.

\begin{tabular}{|c|c|c|c|c|c|}
\hline Biomarker & $\begin{array}{c}\text { Experiment } \\
\text { Format } \\
\end{array}$ & $\begin{array}{l}\text { Basal-like } \\
\text { Definition }\end{array}$ & $\begin{array}{l}\text { Frequency Among } \\
\text { Basal-like }(\%)^{*}, * *\end{array}$ & $\begin{array}{l}\text { Frequency Among } \\
\text { Non-basal-like (\%) }\end{array}$ & $\begin{array}{l}\text { Literature } \\
\text { References }\end{array}$ \\
\hline p16 (strong) & Whole sections & GEP & $22 / 33(69)$ & $10 / 86(12)$ & {$[140]$} \\
\hline Cyclin $\mathbf{E}^{*}$ & Whole sections & Basal CK & $41 / 92(45)$ & $22 / 150(15)$ & {$[130]$} \\
\hline \multirow[t]{3}{*}{ Ki67 } & TMA & Combined & $6 / 11(55)$ & $27 / 125(22)$ & {$[4]$} \\
\hline & Whole sections & Basal CK & $15 / 19(79)$ & $32 / 83(39)$ & {$[127]$} \\
\hline & Whole sections & Basal CK & $39 / 49(80)$ & $81 / 278(29)$ & [169] \\
\hline IMP3* & Whole sections & TNP & $25 / 32(78)$ & 20/106 (19) & {$[162]$} \\
\hline ALDH1 & Combined & Combined & 9/23 (39) & $24 / 160(15)$ & {$[164]$} \\
\hline AQP1* & TMA & TNP & $10 / 45(22)$ & 1/157 (0) & {$[165]$} \\
\hline PPH3* & Whole sections & Combined & $19 / 21(90)$ & $65 / 219(30)$ & {$[168]$} \\
\hline P-glycoprotein & Whole sections & Basal CK & $29 / 49(59)$ & $85 / 278(31)$ & [169] \\
\hline CAIX * & Whole sections & Combined & $16 / 62(26)$ & 43/394 (11) & {$[40]$} \\
\hline \multirow[t]{2}{*}{ FABP7** } & TMA & Basal CK & $43 / 155(28)$ & $40 / 393(10)$ & {$[10]$} \\
\hline & Whole sections & Combined & $10 / 11(91)$ & $14 / 77(18)$ & {$[171]$} \\
\hline \multirow[t]{2}{*}{$\alpha \mathrm{B}-$ crystallin $* * *$} & TMA & Combined & $18 / 40(45)$ & $17 / 288(6)$ & {$[172]$} \\
\hline & Whole sections & Combined & $26 / 32(81)$ & $0 / 21(0)$ & [173] \\
\hline
\end{tabular}

* Biomarker shown to be an independent prognostic factor.

** Distinguishes between good and poor prognostic groups within the set of basal-like tumors.

TMA = Tissue microarray; Basal CK = defined by basal cytokeratin(s) positivity; TNP = Triple negative phenotype; Combined $=$ defined as TNP plus a positive basal-like biomarker including, but not limited to, basal CKs; GEP = Gene expression profile; ND = No data NS = Not specified

\section{What Is Next in Basal-like Breast Cancer Biomarker Research?}

For many biomarkers of basal-like breast cancer, validation studies (ideally from independent groups) are required, as sensitivity and specificity issues arising due to the use of multiple different cut-offs are unavoidable without the establishment of technical standards. Even the commonly-used triple negative definition suffers from these inconsistencies, as both $1 \%$ and $10 \%$ cut-offs for ER and PR are widespread. Consequently, the detection of basal-like breast cancers using the TNP definition yields variable results with a higher cut-off (e.g., 10\%) increasing the sensitivity of the definition at the expense of specificity. Basal cytokeratins, nestin, caveolins 1 and 2, P-cadherin, EGFR and $\alpha \mathrm{B}-$ crystallin are some of the better characterized basal-like biomarkers, yet most must still be considered to remain in a developmental phase, in which the data-driven cutpoint optimization used in a majority of the original studies requires validation. In turn, considerably more research is necessary before any single biomarker is ready for clinical application.

Even where technical issues are worked out and clinical application is practical, clinical utility typically requires predictive, rather than merely prognostic value. Further adding to the lengthy introductory process of biomarkers into routine analysis, prospective randomized clinical trials are the usual route that must be taken to achieve practice-changing, Level 1 evidence, and such trials are few and very rarely conducted for predictive biomarkers. Existing breast cancer trials with completed long term follow-up were mostly designed prior to the recognition of the basal-like subtype. Nevertheless, 
using archived tissue specimens from completed clinical trials, the criteria to obtain Level 1 evidence to facilitate implementation of a biomarker into clinical practice was recently published by Simon et al. [34], in which a rigorous definition of assay methodology and interpretation, including an entirely pre-specified plan for statistical analysis, is mandatory. Initial work in this regard has suggested, for example, an association of the basal-like phenotype with benefits from adjuvant taxanes but not anthracyclines [35]. In addition, Cheang et al. [41] recently presented data suggesting that basal-like breast cancers derive superior benefit from cyclophosphomide-methotrexate-fluorouracil (CMF) over a more widely-employed anthracycline-based treatment regimen (cyclophosphomideepirubicin-fluorouracil; CEF). In both these studies, use of a broader triple negative definition resulted in a loss of statistical significance, emphasizing how use of better biomarker panels and more precise definitions may be required to identify the best treatment for women with basal-like breast cancers. For example, an equal or superior response of basal-like breast carcinomas to non-anthracycline chemotherapies has implications for the delivery of optimal care for patients, since anthracyclinecontaining regimens (a standard therapy) have the potential for specific side effects, such as cardiotoxicity [174].

Understandably, candidate biomarkers selected to undergo the rigorous testing and validation process for approval must be chosen wisely for the sake of time, cost and preservation of valuable resources. To meet these challenges, a logical next step in basal-like breast cancer biomarker research is to determine the immunohistochemical sensitivity and specificity of as many proposed biomarkers as possible relative to a gene expression profile gold standard. A multi-marker immunohistochemical panel consisting of the best biomarkers could then be assembled to maximize sensitivity and specificity for basal-like breast cancer. After further evaluation on well-characterized breast tumor specimens from independent cohorts and clinical trials, the final product would be a thoroughly validated, practical and clinically-accessible assay suitable for novel applications in the management of basal-like breast cancer patients.

While the described process may seem straightforward in concept, its successful execution is dependent on several factors requiring special consideration. First, standard and commerciallyavailable immunohistochemistry-grade antibodies with demonstrated robustness and sensitivity should be used to ensure assay consistency. Moreover, staining protocols must be standardized and subject to quality control. A stringent approach is of great importance for an immunohistochemistry-based clinical assay since interpretation of results can be easily confounded seemingly due to minor procedural inconsistencies, such as using different antibody clones. In addition, monoclonal antibodies are preferred to polyclonals for their superior specificity and subsequently reduced background staining levels which, in turn, lead to decreased inter-observer and technical variation. This approach has been successful in lymphoma subtyping, for example [175]. Even so, it is possible that immunohistochemical approaches may not be up to the task, and gene expression measurements applicable to formalin-fixed paraffin-embedded specimens may provide the necessary means [54,176-178].

Second, access to a large collection of breast tumor specimens with extensive follow-up is a requirement for meaningful exploratory analyses, let alone for confirmation of the prognostic and predictive value of a biomarker panel. Unfortunately, despite abundance of formalin-fixed paraffinembedded breast cancer samples in hospital archives, comprehensive outcome data is restricted to a limited number of large research institutions and cancer cooperative groups. Given the considerable 
sample size needed for sufficient statistical power, a tissue microarray platform is a useful technique to efficiently pursue such investigations. Once again, access to necessary resource tissues as well as the equipment and expertise for such tissue microarray research is limited. A third commonly underestimated factor in immunohistochemical assay development is the meticulous statistical evaluation and laborious model building that must be uniformly conducted with utmost care. Determining the best immunopanel will undoubtedly involve striking a balance between optimizing sensitivity/specificity and practical limits on the number of biomarkers in a panel [179].

Finally, other than a prospective clinical trial specifically designed to address the optimized immunopanel, the highest level of evidence that provides grounds for proposing a change in medical practice must be obtained from two or more consistent retrospective-prospective studies that illustrate the clinical utility of assessing combinatorial expression of the selected biomarkers that comprise the optimized immunopanel [34]. However, the value and scarcity of clinical trial specimens inherently leads to many restrictions on their use, and applications for tissue access can take months and even years to be approved. Nonetheless, these steps must be taken in order to identify the true value of basal-like breast cancer biomarkers and translate this into improved patient care, ultimately giving those afflicted by these aggressive carcinomas the best chance of a cure.

\section{Conclusions}

Basal-like breast cancer accounts for a disproportionately high number of breast cancer-related deaths [180], and due to limited treatment options and lack of targeted therapies will continue to present a significant clinical challenge until more effective interventions are discovered. However, before we can translate existing knowledge into medical diagnosis and treatment, a clinically-practical assay that can reliably identify basal-like carcinomas is necessary. Current immunohistochemical definitions for basal-like breast cancer have limited sensitivity and/or specificity, hindering implementation into routine analysis. This illustrates the need to refine the immunohistochemical classification or develop alternative approaches. Validated biomarkers with high sensitivity and/or specificity against a gene expression profile gold standard can then be used to either build a novel immunohistochemical classifier or improve the performance of existing definitions. The assembly of a definitive immunopanel that accurately identifies the basal-like subtype will enable research to be undertaken in a more significant and meaningful context with regards to basal-like breast carcinoma biology, prognosis and prediction of therapeutic response. This would allow optimal selection from current management options and facilitate efficient development of new targeted therapies.

\section{Acknowledgements}

The authors would like to thank Suzanne Liu for helpful comments on the manuscript as well as Dongxia (Doris) Gao and Samuel Leung for help with figure preparation.

\section{References}

1. Perou, C.M.; Sorlie, T.; Eisen, M.B.; van de Rijn, M.; Jeffrey, S.S.; Rees, C.A.; Pollack, J.R.; Ross, D.T.; Johnsen, H.; Akslen, L.A.; et al. Molecular portraits of human breast tumours. Nature 2000, 406, 747-752. 
2. Sorlie, T.; Perou, C.M.; Tibshirani, R.; Aas, T.; Geisler, S.; Johnsen, H.; Hastie, T.; Eisen, M.B.; van de Rijn, M.; Jeffrey, S.S.; et al. Gene expression patterns of breast carcinomas distinguish tumor subclasses with clinical implications. Proc. Natl. Acad. Sci. USA 2001, 98, 10869-10874.

3. van't Veer, L.J.; Paik, S.; Hayes, D.F. Gene Expression Profiling of Breast Cancer: A New Tumor Marker. J. Clin. Oncol. 2005, 23, 1631-1635.

4. Matos, I.; Dufloth, R.; Alvarenga, M.; Zeferino, L.; Schmitt, F. p63, cytokeratin 5, and Pcadherin: three molecular markers to distinguish basal phenotype in breast carcinomas. Virchows Arch. 2005, 447, 688-694.

5. Nielsen, T.O.; Hsu, F.D.; Jensen, K.; Cheang, M.; Karaca, G.; Hu, Z.; Hernandez-Boussard, T.; Livasy, C.; Cowan, D.; Dressler, L.; et al. Immunohistochemical and Clinical Characterization of the Basal-Like Subtype of Invasive Breast Carcinoma. Clin. Cancer Res. 2004, 10, 5367-5374.

6. $\quad$ van de Rijn, M.; Perou, C.M.; Tibshirani, R.; Haas, P.; Kallioniemi, O.; Kononen, J.; Torhorst, J.; Sauter, G.; Zuber, M.; Kochli, O.R.; et al. Expression of Cytokeratins 17 and 5 Identifies a Group of Breast Carcinomas with Poor Clinical Outcome. Am. J. Pathol. 2002, 161, 1991-1996.

7. Bertucci, F.; Finetti, P.; Cervera, N.; Charafe-Jauffret, E.; Buttarelli, M.; Jacquemier, J.; Chaffanet, M.; Maraninchi, D.; Viens, P.; Birnbaum, D. How different are luminal A and basal breast cancers? Int. J. Cancer 2009, 124, 1338-1348.

8. Linn, S.C.; van't Veer, L.J. Clinical relevance of the triple-negative breast cancer concept: Genetic basis and clinical utility of the concept. Eur. J. Cancer 2009, 45, 11-26.

9. Rakha, E.; El-Sayed, M.; Reis-Filho, J.; Ellis, I. Patho-biological aspects of basal-like breast cancer. Breast Cancer Res. Treat. 2009, 113, 411-422.

10. Zhang, H.; Rakha, E.; Ball, G.; Spiteri, I.; Aleskandarany, M.; Paish, E.; Powe, D.; Macmillan, R.; Caldas, C.; Ellis, I.; et al. The proteins FABP7 and OATP2 are associated with the basal phenotype and patient outcome in human breast cancer. Breast Cancer Res. Treat. 2009, 121, 41-51.

11. Carey, L.A.; Perou, C.M.; Livasy, C.A.; Dressler, L.G.; Cowan, D.; Conway, K.; Karaca, G.; Troester, M.A.; Tse, C.K.; Edmiston, S.; et al. Race, Breast Cancer Subtypes, and Survival in the Carolina Breast Cancer Study. J Am. Med. Assoc. 2006, 295, 2492-2502.

12. Cheang, M.C.U.; Voduc, D.; Bajdik, C.; Leung, S.; McKinney, S.; Chia, S.K.; Perou, C.M.; Nielsen, T.O. Basal-Like Breast Cancer Defined by Five Biomarkers Has Superior Prognostic Value than Triple-Negative Phenotype. Clin. Cancer Res. 2008, 14, 1368-1376.

13. El-Rehim, D.M.A.; Pinder, S.E.; Paish, C.E.; Bell, J.; Blamey, R.W.; Robertson, J.F.R.; Nicholson, R.I.; Ellis, I.O. Expression of luminal and basal cytokeratins in human breast carcinoma. J. Pathol. 2004, 203, 661-671.

14. Reis-Filho, J.S.; Milanezi, F.; Steele, D.; Savage, K.; Simpson, P.T.; Nesland, J.M.; Pereira, E.M.; Lakhani, S.R.; Schmitt, F.C. Metaplastic breast carcinomas are basal-like tumours. Histopathology 2006, 49, 10-21.

15. Lae, M.; Freneaux, P.; Sastre-Garau, X.; Chouchane, O.; Sigal-Zafrani, B.; Vincent-Salomon, A. Secretory breast carcinomas with ETV6-NTRK3 fusion gene belong to the basal-like carcinoma spectrum. Mod. Pathol. 2008, 22, 291-298.

16. Bertucci, F.; Finetti, P.; Cervera, N.; Charafe-Jauffret, E.; Mamessier, E.; Adelaide, J.; Debono, S.; Houvenaeghel, G.; Maraninchi, D.; Viens, P.; et al. Gene Expression Profiling Shows 
Medullary Breast Cancer Is a Subgroup of Basal Breast Cancers. Cancer Res. 2006, 66, 4636-4644.

17. Azoulay, S.; Lae, M.; Freneaux, P.; Merle, S.; Al Ghuzlan, A.; Chnecker, C.; Rosty, C.; Klijanienko, J.; Sigal-Zafrani, B.; Salmon, R.; et al. KIT is highly expressed in adenoid cystic carcinoma of the breast, a basal-like carcinoma associated with a favorable outcome. Mod. Pathol. 2005, 18, 1623-1631.

18. Weigelt, B.; Mackay, A.; A'Hern, R.; Natrajan, R.; Tan, D.S.P.; Dowsett, M.; Ashworth, A.; Reis-Filho, J.S. Breast cancer molecular profiling with single sample predictors: a retrospective analysis. Lancet Oncol. 2010, 11, 339-349.

19. Sorlie, T.; Tibshirani, R.; Parker, J.; Hastie, T.; Marron, J.S.; Nobel, A.; Deng, S.; Johnsen, H.; Pesich, R.; Geisler, S.; et al. Repeated observation of breast tumor subtypes in independent gene expression data sets. Proc. Natl. Acad. Sci. 2003, 100, 8418-8423.

20. Stingl, J.; Caldas, C. Molecular heterogeneity of breast carcinomas and the cancer stem cell hypothesis. Nat. Rev. Cancer 2007, 7, 791-799.

21. Lim, E.; Vaillant, F.; Wu, D.; Forrest, N.C.; Pal, B.; Hart, A.H.; Asselin-Labat, M.-L.; Gyorki, D.E.; Ward, T.; Partanen, A.; et al. Aberrant luminal progenitors as the candidate target population for basal tumor development in BRCA1 mutation carriers. Nat. Med. 2009, 15, 907-913.

22. Bocker, W.; Moll, R.; Poremba, C.; Holland, R.; van Diest, P.J.; Dervan, P.; Burger, H.; Wai, D.; Ina Diallo, R.; Brandt, B.; et al. Common Adult Stem Cells in the Human Breast Give Rise to Glandular and Myoepithelial Cell Lineages: A New Cell Biological Concept. Lab. Invest. 2002, $82,737-746$.

23. Gusterson, B. Do 'basal-like' breast cancers really exist? Nat. Rev. Cancer. 2009, 9, 128-134.

24. Gusterson, B.; Ross, D.; Heath, V.; Stein, T. Basal cytokeratins and their relationship to the cellular origin and functional classification of breast cancer. Breast Cancer Res. 2005, 7, 143-148.

25. Ramachandran, N.; Srivastava, S.; LaBaer, J. Applications of protein microarrays for biomarker discovery. Proteomics 2008, 2, 1444-1459.

26. Fadare, O.; Tavassoli, F.A. Clinical and pathologic aspects of basal-like breast cancers. Nat. Clin. Prac. Oncol. 2008, 5, 149-159.

27. Ross, J.S.; Linette, G.P.; Stec, J.; Clark, E.; Ayers, M.; Leschly, N.; Symmans, W.F.; Hortobagyi, G.N.; Pusztai, L. Breast cancer biomarkers and molecular medicine: part II. Expert Rev. Mol. Diagn. 2004, 4, 169-188.

28. Tainsky, M.A. Genomic and proteomic biomarkers for cancer: A multitude of opportunities. Biochim. Biophys. Acta Rev. Cancer 2009, 1796, 176-193.

29. Ward, T.H.; Cummings, J.; Dean, E.; Greystoke, A.; Hou, J.M.; Backen, A.; Ranson, M.; Dive, C. Biomarkers of apoptosis. Br. J. Cancer 2008, 99, 841-846.

30. Mohammadizadeh, F.; Naimi, A.; Rajabi, P.; Ghasemibasir, H.; Eftekhari, A. Expression of basal and luminal cytokeratins in breast cancer and their correlation with clinicopathological prognostic variables. Indian J. Med. Sci. 2009, 63, 152-162.

31. Camp, R.L.; Neumeister, V.; Rimm, D.L. A Decade of Tissue Microarrays: Progress in the Discovery and Validation of Cancer Biomarkers. J. Clin. Oncol. 2008, 26, 5630-5637. 
32. Tang, P.; Skinner, K.A.; Hicks, D.G. Molecular Classification of Breast Carcinomas by Immunohistochemical Analysis: Are We Ready? Diagn. Mol. Pathol. 2009, 18, 125-132.

33. Simon, R. Advances in clinical trial designs for predictive biomarker discovery and validation. Curr. Breast Cancer Rep. 2009, 1, 216-221.

34. Simon, R.M.; Paik, S.; Hayes, D.F. Use of Archived Specimens in Evaluation of Prognostic and Predictive Biomarkers. J. Natl. Cancer Inst. 2009, djp335.

35. Nielsen, T.O.; Jewell, S.D.; Thor, A.D.; Gao, D.; Perou, C.M.; Broadwater, G.; Harris, L.N.; Hayes, D.F.; Berry, D.A.; Ellis, M.J. Intrinsic subtype and response to paclitaxel in CALGB 9344 tissue microarrays. Presented at the ASCO 2009 Breast Cancer Symposium, San Francisco, CA, USA, October 2009.

36. Bertucci, F.; Finetti, P.; Cervera, N.; Esterni, B.; Hermitte, F.; Viens, P.; Birnbaum, D. How basal are triple-negative breast cancers? Int. J. Cancer 2008, 123, 236-240.

37. Wang, X.; Chao, L.; Ma, G.; Chen, L.; Tian, B.; Zang, Y.; Sun, J. Increased expression of osteopontin in patients with triple-negative breast cancer. Eur. J. Clin. Invest. 2008, 38, 438-446.

38. Kim, J.M.; Hwang, T.Y.; Kang, S.H.; Lee, S.J.; Bae, Y.K. Prognostic Significance of Basal Markers in Triple-negative Breast Cancers. J. Breast Cancer 2009, 12, 4-13.

39. Martín, M.; Rodríguez-Lescure, Á.; Ruiz, A.; Alba, E.; Calvo, L.; Ruiz-Borrego, M.; Santaballa, A.; Rodríguez, C.; Crespo, C.; Abad, M.; et al. Molecular predictors of efficacy of adjuvant weekly paclitaxel in early breast cancer. Breast Cancer Res. Treat. 2009, [Epub ahead of print].

40. Tan, E.Y.; Yan, M.; Campo, L.; Han, C.; Takano, E.; Turley, H.; Candiloro, I.; Pezzella, F.; Gatter, K.C.; Millar, E.K.A.; et al. The key hypoxia regulated gene CAIX is upregulated in basallike breast tumours and is associated with resistance to chemotherapy. Br. J. Cancer 2009, 100, 405-411.

41. Cheang, M.; Chia, S.K.; Tu, D.; Jiang, S.; Shepherd, L.E.; Pritchard, K.I.; Nielsen, T.O. Anthracyclines in basal breast cancer: The NCIC-CTG trial MA5 comparing adjuvant CMF to CEF. Presented at the 2009 ASCO Annual Meeting, Orlando, FL, USA, May 2009.

42. Voduc, D.; Nielsen, T. Basal and Triple-Negative Breast Cancers: Impact on Clinical DecisionMaking and Novel Therapeutic Options. Clin. Breast Cancer 2008, 8, s171-s178.

43. Rakha, E.A.; Elsheikh, S.E.; Aleskandarany, M.A.; Habashi, H.O.; Green, A.R.; Powe, D.G.; El-Sayed, M.E.; Benhasouna, A.; Brunet, J.S.; Akslen, L.A.; et al. Triple-Negative Breast Cancer: Distinguishing between Basal and Nonbasal Subtypes. Clin. Cancer Res. 2009, 15, 2302-2310.

44. Laakso, M.; Loman, N.; Borg, A.; Isola, J. Cytokeratin 5/14-positive breast cancer: true basal phenotype confined to BRCA1 tumors. Mod. Pathol. 2005, 18, 1321-1328.

45. Potemski, P.; Kusinska, R.; Watala, C.; Pluciennik, E.; Bednarek, A.K.; Kordek, R. Prognostic Relevance of Basal Cytokeratin Expression in Operable Breast Cancer. Oncology 2005, 69, 478-485.

46. Rakha, E.A.; El-Sayed, M.E.; Green, A.R.; Paish, E.C.; Lee, A.H.S.; Ellis, I.O. Breast carcinoma with basal differentiation: a proposal for pathology definition based on basal cytokeratin expression. Histopathology 2007, 50, 434-438. 
47. Malzahn, K.; Mitze, M.; Thoenes, M.; Moll, R. Biological and prognostic significance of stratified epithelial cytokeratins in infiltrating ductal breast carcinomas. Virchows Arch. 1998, 433, 119-129.

48. Dairkee, S.H.; Puett, L.; Hackett, A.J. Expression of Basal and Luminal Epithelium-Specific Keratins in Normal, Benign, and Malignant Breast Tissue1. J. Natl. Cancer Inst. 1988, 80, 691-695.

49. Wetzels, R.H.; Kuijpers, H.J.; Lane, E.B.; Leigh, I.M.; Troyanovsky, S.M.; Holland, R.; van Haelst, U.J.; Ramaekers, F.C. Basal cell-specific and hyperproliferation-related keratins in human breast cancer. Am. J. Pathol. 1991, 138, 751-763.

50. Wetzels, R.H.; Holland, R.; van Haelst, U.J.; Lane, E.B.; Leigh, I.M.; Ramaekers, F.C. Detection of basement membrane components and basal cell keratin 14 in noninvasive and invasive carcinomas of the breast. Am. J. Pathol. 1989, 134, 571-579.

51. Chen, P.C.; Chen, C.K.; Nicastri, A.D.; Wait, R.B. Myoepithelial carcinoma of the breast with distant metastasis and accompanied by adenomyoepitheliomas. Histopathology 1994, 24, 543-548.

52. Livasy, C.A.; Karaca, G.; Nanda, R.; Tretiakova, M.S.; Olopade, O.I.; Moore, D.T.; Perou, C.M. Phenotypic evaluation of the basal-like subtype of invasive breast carcinoma. Mod. Pathol. 2005, 19, 264-271.

53. Thike, A.A.; Cheok, P.Y.; Jara-Lazaro, A.R.; Tan, B.; Tan, P.; Tan, P.H. Triple-negative breast cancer: clinicopathological characteristics and relationship with basal-like breast cancer. Mod. Pathol. 2009, 23, 123-133.

54. Parker, J.S.; Mullins, M.; Cheang, M.C.U.; Leung, S.; Voduc, D.; Vickery, T.; Davies, S.; Fauron, C.; He, X.; Hu, Z.; et al. Supervised Risk Predictor of Breast Cancer Based on Intrinsic Subtypes. J. Clin. Oncol. 2009, 27, 1160-1167.

55. Liu, Z.B.; Wu, J.; Ping, B.; Feng, L.Q.; Lu, J.S.; Shen, K.W.; Shen, Z.Z.; Shaol, Z.M. Basal cytokeratin expression in relation to immunohistochemical and clinical characterization in breast cancer patients with triple-negative phenotype. Tumori 2009, 95, 53-62.

56. Chen, M.H.S.; Wai-Cheong Yip, G.; Tse, G.M.-K.; Moriya, T.; Lui, P.C.-W.; Zin, M.-L.; Bay, B.-H.; Tan, P.-H. Expression of basal keratins and vimentin in breast cancers of young women correlates with adverse pathologic parameters. Mod. Pathol. 2008, 21, 1183-1191.

57. Rodriguez-Pinilla, S.M.; Sarrio, D.; Honrado, E.; Moreno-Bueno, G.; Hardisson, D.; Calero, F.; Benitez, J.; Palacios, J. Vimentin and laminin expression is associated with basal-like phenotype in both sporadic and BRCA1-associated breast carcinomas. J. Clin. Pathol. 2007, 60, 1006-1012.

58. Sarrio, D.; Rodriguez-Pinilla, S.M.; Hardisson, D.; Cano, A.; Moreno-Bueno, G.; Palacios, J. Epithelial-Mesenchymal Transition in Breast Cancer Relates to the Basal-like Phenotype. Cancer Res. 2008, 68, 989-997.

59. Rodriguez-Pinilla, S.M.; Sarrio, D.; Honrado, E.; Hardisson, D.; Calero, F.; Benitez, J.; Palacios, J. Prognostic Significance of Basal-Like Phenotype and Fascin Expression in Node-Negative Invasive Breast Carcinomas. Clin. Cancer Res. 2006, 12, 1533-1539.

60. Yoder, B.J.; Tso, E.; Skacel, M.; Pettay, J.; Tarr, S.; Budd, T.; Tubbs, R.R.; Adams, J.C.; Hicks, D.G. The Expression of Fascin, an Actin-Bundling Motility Protein, Correlates with Hormone 
Receptor-Negative Breast Cancer and a More Aggressive Clinical Course. Clin. Cancer Res. 2005, 11, 186-192.

61. Caigang, L.; Bo, C.; Jun, Z.; Ruishan, Z.; Fan, Y.; Feng, J.; Huimian, X.; Ping, L. Clinical implications for nestin protein expression in breast cancer. Cancer Sci. 2009, 101, 815-819.

62. Li, H.; Cherukuri, P.; Li, N.; Cowling, V.; Spinella, M.; Cole, M.; Godwin, A.K.; Wells, W.; DiRenzo, J. Nestin Is Expressed in the Basal/Myoepithelial Layer of the Mammary Gland and Is a Selective Marker of Basal Epithelial Breast Tumors. Cancer Res. 2007, 67, 501-510.

63. Parry, S.; Savage, K.; Marchio, C.; Reis-Filho, J.S. Nestin is expressed in basal-like and triple negative breast cancers. J. Clin. Pathol. 2008, 61, 1045-1050.

64. Charafe-Jauffret, E.; Ginestier, C.; Monville, F.; Finetti, P.; Adelaide, J.; Cervera, N.; Fekairi, S.; Xerri, L.; Jacquemier, J.; Birnbaum, D.; et al. Gene expression profiling of breast cell lines identifies potential new basal markers. Oncogene 2005, 25, 2273-2284.

65. Charafe-Jauffret, E.; Monville, F.; Bertucci, F.; Esterni, B.; Ginestier, C.; Finetti, P.; Cervera, N.; Geneix, J.; Hassanein, M.; Rabayrol, L.; et al. Moesin expression is a marker of basal breast carcinomas. Int. J. Cancer 2007, 121, 1779-1785.

66. Kusinska, R.; Kordek, R.; Pluciennik, E.; Bednarek, A.; Piekarski, J.; Potemski, P. Does vimentin help to delineate the so-called 'basal type breast cancer'? J. Exp. Clin. Cancer Res. 2009, 28, 118-126.

67. Ouban, A.; Ahmed, A.A. Claudins in human cancer: A review. Histol. Histopathol. 2010, 25, 83-90.

68. Blanchard, A.; Skliris, G.; Watson, P.; Murphy, L.; Penner, C.; Tomes, L.; Young, T.; Leygue, E.; Myal, Y. Claudins 1, 3, and 4 protein expression in ER negative breast cancer correlates with markers of the basal phenotype. Virchows Arch. 2009, 454, 647-656.

69. Kulka, J.; Szász, A.; Németh, Z.; Madaras, L.; Schaff, Z.; Molnár, I.; Tőkés, A.-M. Expression of Tight Junction Protein Claudin-4 in Basal-Like Breast Carcinomas. Pathol. Oncol. Res. 2009, 15, 59-64.

70. Lanigan, F.; McKiernan, E.; Brennan, D.J.; Hegarty, S.; Millikan, R.C.; McBryan, J.; Jirstrom, K.; Landberg, G.; Martin, F.; Duffy, M.J.; et al. Increased claudin-4 expression is associated with poor prognosis and high tumour grade in breast cancer. Int. J. Cancer 2009, 124, 2088-2097.

71. Elsheikh, S.E.; Green, A.R.; Rakha, E.A.; Samaka, R.M.; Ammar, A.A.; Powe, D.; Reis-Filho, J.S.; Ellis, I.O. Caveolin 1 and Caveolin 2 are associated with breast cancer basal-like and triplenegative immunophenotype. Br. J. Cancer 2008, 99, 327-334.

72. Pinilla, S.; Honrado, E.; Hardisson, D.; Benítez, J.; Palacios, J. Caveolin-1 expression is associated with a basal-like phenotype in sporadic and hereditary breast cancer. Breast Cancer Res. Treat. 2006, 99, 85-90.

73. Savage, K.; Lambros, M.B.K.; Robertson, D.; Jones, R.L.; Jones, C.; Mackay, A.; James, M.; Hornick, J.L.; Pereira, E.M.; Milanezi, F.; et al. Caveolin 1 Is Overexpressed and Amplified in a Subset of Basal-like and Metaplastic Breast Carcinomas: A Morphologic, Ultrastructural, Immunohistochemical, and In situ Hybridization Analysis. Clin. Cancer Res. 2007, 13, 90-101.

74. Savage, K.; Leung, S.; Todd, S.; Brown, L.; Jones, R.; Robertson, D.; James, M.; Parry, S.; Rodrigues-Pinilla, S.; Huntsman, D.; et al. Distribution and significance of caveolin 2 expression 
in normal breast and invasive breast cancer: an immunofluorescence and immunohistochemical analysis. Breast Cancer Res. Treat. 2008, 110, 245-256.

75. Sloan, E.K.; Ciocca, D.R.; Pouliot, N.; Natoli, A.; Restall, C.; Henderson, M.A.; Fanelli, M.A.; Cuello-Carrion, F.D.; Gago, F.E.; Anderson, R.L. Stromal Cell Expression of Caveolin-1 Predicts Outcome in Breast Cancer. Am. J. Pathol. 2009, 174, 2035-2043.

76. Witkiewicz, A.K.; Dasgupta, A.; Sammons, S.; Er, O.; Potoczek, M.B.; Guiles, F.; Sotgia, F.; Brody, J.R.; Mitchell, E.P.; Lisanti, M.P. Loss of stromal caveolin-1 expression predicts poor clinical outcome in triple negative and basal-like breast cancers. Cancer Biol. Ther. 2010, 2, Epub ahead of print.

77. Humphries, M.J.; Reynolds, A. Cell-to-cell contact and extracellular matrix. Curr. Opin. Cell Biol. 2009, 21, 613-615.

78. Helleman, J.; Jansen, M.P.H.M.; Ruigrok-Ritstier, K.; van Staveren, I.L.; Look, M.P.; Meijer-van Gelder, M.E.; Sieuwerts, A.M.; Klijn, J.G.M.; Sleijfer, S.; Foekens, J.A.; et al. Association of an Extracellular Matrix Gene Cluster with Breast Cancer Prognosis and Endocrine Therapy Response. Clin. Cancer Res. 2008, 14, 5555-5564.

79. Lakhani, S.R.; Reis-Filho, J.S.; Fulford, L.; Penault-Llorca, F.; van der Vijver, M.; Parry, S.; Bishop, T.; Benitez, J.; Rivas, C.; Bignon, Y.-J.; et al. Prediction of BRCA1 Status in Patients with Breast Cancer Using Estrogen Receptor and Basal Phenotype. Clin. Cancer Res. 2005, 11, 5175-5180.

80. Jones, C.; Mackay, A.; Grigoriadis, A.; Cossu, A.; Reis-Filho, J.S.; Fulford, L.; Dexter, T.; Davies, S.; Bulmer, K.; Ford, E.; et al. Expression Profiling of Purified Normal Human Luminal and Myoepithelial Breast Cells: Identification of Novel Prognostic Markers for Breast Cancer. Cancer Res. 2004, 64, 3037-3045.

81. Rodrigues, L.R.; Lopes, N.; Sousa, B.; Vieira, D.; Milanezi, F.; Paulsson, M.; LindmarkMansson, H.; Teixeira, J.A.; Schmitt, F. Significance of osteopontin expression in human invasive breast tumour stroma. Open Breast Cancer J. 2009, 1, 1-9.

82. Wai, P.; Kuo, P. Osteopontin: regulation in tumor metastasis. Cancer Metastasis Rev. 2008, 27, 103-118.

83. Carpenter, P.M.; Dao, A.V.; Arain, Z.S.; Chang, M.K.; Nguyen, H.P.; Arain, S.; WangRodriguez, J.; Kwon, S.-Y.; Wilczynski, S.P. Motility Induction in Breast Carcinoma by Mammary Epithelial Laminin 332 (Laminin 5). Mol. Cancer Res. 2009, 7, 462-475.

84. Marinkovich, M.P. Laminin 332 in squamous-cell carcinoma. Nat. Rev. Cancer 2007, 7, 370-380.

85. Gilcrease, M.; Zhou, X.; Lu, X.; Woodward, W.; Hall, B.; Morrissey, P. Alpha6beta4 integrin crosslinking induces EGFR clustering and promotes EGF-mediated Rho activation in breast cancer. J. Exp. Clin. Cancer Res. 2009, 28, 67.

86. Lu, S.; Simin, K.; Khan, A.; Mercurio, A.M. Analysis of Integrin Beta4 Expression in Human Breast Cancer: Association with Basal-like Tumors and Prognostic Significance. Clin. Cancer Res. 2008, 14, 1050-1058.

87. Reis-Filho, J.S.; Steele, D.; Di Palma, S.; Jones, R.L.; Savage, K.; James, M.; Milanezi, F.; Schmitt, F.C.; Ashworth, A. Distribution and significance of nerve growth factor receptor 
(NGFR/p75NTR) in normal, benign and malignant breast tissue. Mod. Pathol. 2006, 19, 307-319.

88. Hasegawa, M.; Moritani, S.; Murakumo, Y.; Sato, T.; Hagiwara, S.; Suzuki, C.; Mii, S.; Jijiwa, M.; Enomoto, A.; Asai, N.; et al. CD109 expression in basal-like breast carcinoma. Pathol. Int. 2008, 58, 288-294.

89. Arnes, J.B.; Brunet, J.-S.; Stefansson, I.; Begin, L.R.; Wong, N.; Chappuis, P.O.; Akslen, L.A.; Foulkes, W.D. Placental Cadherin and the Basal Epithelial Phenotype of BRCA1-Related Breast Cancer. Clin. Cancer Res. 2005, 11, 4003-4011.

90. Paredes, J.; Lopes, N.; Milanezi, F.; Schmitt, F. P-cadherin and cytokeratin 5: useful adjunct markers to distinguish basal-like ductal carcinomas in situ. Virchows Arch. 2007, 450, 73-80.

91. Potemski, P.; Kusinska, R.; Kubiak, R.; Piekarski, J.H.; Pluciennik, E.; Bednarek, A.K.; Kordek, R. Relationship of P-cadherin expression to basal phenotype of breast carcinoma. Polish J. Pathol. 2007, 58, 183-188.

92. Honeth, G.; Bendahl, P.-O.; Ringner, M.; Saal, L.; Gruvberger-Saal, S.; Lovgren, K.; Grabau, D.; Ferno, M.; Borg, A.; Hegardt, C. The CD44+/CD24- phenotype is enriched in basal-like breast tumors. Breast Cancer Res. Treat. 2008, 10, R53.

93. Klingbeil, P.; Natrajan, R.; Everitt, G.; Vatcheva, R.; Marchio, C.; Palacios, J.; Buerger, H.; ReisFilho, J.; Isacke, C. CD44 is overexpressed in basal-like breast cancers but is not a driver of 11 p13 amplification. Breast Cancer Res. Treat. 2009, 120, 95-109.

94. Wienke, D.; Davies, G.C.; Johnson, D.A.; Sturge, J.; Lambros, M.B.K.; Savage, K.; Elsheikh, S.E.; Green, A.R.; Ellis, I.O.; Robertson, D.; et al. The Collagen Receptor Endo180 (CD280) Is Expressed on Basal-like Breast Tumor Cells and Promotes Tumor Growth In vivo. Cancer Res. 2007, 67, 10230-10240.

95. Garcia, S.; Dalès, J.-P.; Charafe-Jauffret, E.; Carpentier-Meunier, S.; Andrac-Meyer, L.; Jacquemier, J.; Andonian, C.; Lavaut, M.-N.; Allasia, C.; Bonnier, P.; et al. Poor prognosis in breast carcinomas correlates with increased expression of targetable CD146 and c-Met and with proteomic basal-like phenotype. Human Pathol. 2007, 38, 830-841.

96. Graveel, C.R.; DeGroot, J.D.; Su, Y.; Koeman, J.; Dykema, K.; Leung, S.; Snider, J.; Davies, S.R.; Swiatek, P.J.; Cottingham, S.; et al. Met induces diverse mammary carcinomas in mice and is associated with human basal breast cancer. Proc. Natl. Acad. Sci. USA 2009, 106, 12909-12914.

97. Zabouo, G.; Imbert, A.-M.; Jacquemier, J.; Finetti, P.; Moreau, T.; Esterni, B.; Bertucci, F.; Chabannon, C. CD146 expression is associated with a poor prognosis in human breast tumors and with enhanced motility in breast cancer cell lines. Breast Cancer Res. 2009, 11, R1.

98. Ouhtit, A.; Gaur, R.L.; Abd Elmageed, Z.Y.; Fernando, A.; Thouta, R.; Trappey, A.K.; Abdraboh, M.E.; El-Sayyad, H.I.; Rao, P.; Raj, M.G.H. Towards understanding the mode of action of the multifaceted cell adhesion receptor CD146. Biochim. Biophys. Acta 2009, 1795, 130-136.

99. Shih, L.M.; Hsu, M.Y.; Palazzo, J.P.; Herlyn, M. The cell-cell adhesion receptor Mel-CAM acts as a tumor suppressor in breast carcinoma. Am. J. Pathol. 1997, 151, 745-751. 
100. Arnes, J.B.; Begin, L.R.; Stefansson, I.; Brunet, J.S.; Nielsen, T.O.; Foulkes, W.D.; Akslen, L.A. Expression of epidermal growth factor receptor in relation to BRCA1 status, basal-like markers and prognosis in breast cancer. J. Clin. Pathol. 2009, 62, 139-146.

101. Viale, G.; Rotmensz, N.; Maisonneuve, P.; Bottiglieri, L.; Montagna, E.; Luini, A.; Veronesi, P.; Intra, M.; Torrisi, R.; Cardillo, A.; et al. Invasive ductal carcinoma of the breast with the "triplenegative" phenotype: prognostic implications of EGFR immunoreactivity. Breast Cancer Res. Treat. 2009, 116, 317-328.

102. Nalwoga, H. Expression of EGFR and c-kit is associated with the basal-like phenotype in breast carcinomas of African women. Acta Pathol. Microbiol. Immunol. Scandinavica 2008, 116, $515-525$.

103. Stratford, A.; Habibi, G.; Astanehe, A.; Jiang, H.; Hu, K.; Park, E.; Shadeo, A.; Buys, T.; Lam, W.; Pugh, T.; et al. Epidermal growth factor receptor (EGFR) is transcriptionally induced by the Y-box binding protein-1 (YB-1) and can be inhibited with Iressa in basal-like breast cancer, providing a potential target for therapy. Breast Cancer Res. 2007, 9, R61.

104. Linderholm, B.K.; Hellborg, H.; Johansson, U.; Elmberger, G.; Skoog, L.; Lehtio, J.; Lewensohn, R. Significantly higher levels of vascular endothelial growth factor (VEGF) and shorter survival times for patients with primary operable triple-negative breast cancer. Ann. Oncol. 2009, 20, 1639-1646.

105. Ribeiro-Silva, A.; de Vale, F.R.; Zucoloto, S. Vascular endothelial growth factor expression in the basal subtype of breast carcinoma. Am. J. Clin. Pathol. 2006, 125, 512-518.

106. Dent, S. F. The role of VEGF in triple-negative breast cancer: where do we go from here? Ann. Oncol. 2009, 20, 1615-1617.

107. Modjtahedi, H.; Essapen, S. Epidermal growth factor receptor inhibitors in cancer treatment: advances, challenges and opportunities. Anti-Cancer Drugs 2009, 20, 851-855.

108. Shahi, P.K.; Pineda, I.F. Tumoral Angiogenesis: Review of the Literature. Cancer Invest. 2008, 26, 104-108.

109. Sledge, G. VEGF-Targeting Therapy for Breast Cancer. J. Mammary Gland Biol. Neoplasia 2005, 10, 319-323.

110. Tsuda, H.; Morita, D.; Kimura, M.; Shinto, E.; Ohtsuka, Y.; Matsubara, O.; Inazawa, J.; Tamaki, K.; Mochizuki, H.; Tamai, S.; et al. Correlation of KIT and EGFR overexpression with invasive ductal breast carcinoma of the solid-tubular subtype, nuclear grade 3, and mesenchymal or myoepithelial differentiation. Cancer Sci. 2005, 96, 48-53.

111. Dickler, M.; Cobleigh, M.; Miller, K.; Klein, P.; Winer, E. Efficacy and safety of erlotinib in patients with locally advanced or metastatic breast cancer. Breast Cancer Res. Treat. 2009, 115, 115-121.

112. Dickler, M.N.; Rugo, H.S.; Eberle, C.A.; Brogi, E.; Caravelli, J.F.; Panageas, K.S.; Boyd, J.; Yeh, B.; Lake, D.E.; Dang, C.T.; et al. A Phase II Trial of Erlotinib in Combination with Bevacizumab in Patients with Metastatic Breast Cancer. Clin. Cancer Res. 2008, 14, 7878-7883.

113. Flynn, J.F.; Wong, C.; Wu, J.M. Anti-EGFR therapy: mechanism and advances in clinical efficacy in breast cancer. J. Oncol. 2009, 2009, 526963. 
114. Modi, S.; D'Andrea, G.; Norton, L.; Yao, T.J.; Caravelli, J.; Rosen, P.; Hudis, C.; Seidman, A. A Phase I Study of Cetuximab/Paclitaxel in Patients with Advanced-Stage Breast Cancer. Clin. Breast Cancer 2006, 7, 270-277.

115. Carey, L.A.; Rugo, H.S.; Marcom, P.K.; Irvin, W., Jr.; Ferraro, M.; Burrows, E.; He, X.; Perou, C.M.; Winer, E.P. TBCRC 001: EGFR inhibition with cetuximab added to carboplatin in metastatic triple-negative (basal-like) breast cancer. Presented at the 2008 ASCO Annual Meeting, Boston, MA, June 2008.

116. Conte, P.; Guarneri, V. Triple-negative breast cancer: current management and future options. Eur. J. Cancer Suppl. 2009, 7, 14-18.

117. Chia, K.; Tutt, A. Triple-negative breast cancer: an update. Adv. Breast Cancer 2007, 4, 75-80.

118. Saeki, R.; Kondoh, M.; Kakutani, H.; Tsunoda, S.-i.; Mochizuki, Y.; Hamakubo, T.; Tsutsumi, Y.; Horiguchi, Y.; Yagi, K. A Novel Tumor-Targeted Therapy Using a Claudin-4-Targeting Molecule. Mol. Pharmacol. 2009, 76, 918-926.

119. Rodriguez-Pinilla, S.M.; Sarrio, D.; Moreno-Bueno, G.; Rodriguez-Gil, Y.; Martinez, M.A.; Hernandez, L.; Hardisson, D.; Reis-Filho, J.S.; Palacios, J. Sox2: a possible driver of the basallike phenotype in sporadic breast cancer. Mod. Pathol. 2007, 20, 474-481.

120. Ray, P.S.; Wang, J.; Qu, Y.; Shin-Sim, M.; Shamonki, J.; Liu, B.; Elashoff, D.; Hoon, D.S.; Giuliano, A.E.; Cui, X. Diagnostic and prognostic significance of FOXC1 expression in basallike/triple-negative breast cancer. Poster presented at the ASCO 2009 Breast Cancer Symposium, San Francisco, CA, USA, October 2009.

121. Ray, P.S.; Wang, J.; Qu, Y.; Shin-Sim, M.; Shamonki, J.; Liu, B.; Hoon, D.S.; Giuliano, A.E.; Cui, X. Role of FOXC1 in regulation of basal-like/triple-negative breast cancer. Presented at the 2009 ASCO Annual Meeting, Orlando, FL, USA, May 2009.

122. Mani, S.A.; Yang, J.; Brooks, M.; Schwaninger, G.; Zhou, A.; Miura, N.; Kutok, J.L.; Hartwell, K.; Richardson, A.L.; Weinberg, R.A. Mesenchyme Forkhead 1 (FOXC2) plays a key role in metastasis and is associated with aggressive basal-like breast cancers. Proc. Natl. Acad. Sci. USA 2007, 104, 10069-10074.

123. Umemura, S.; Shirane, M.; Takekoshi, S.; Kusakabe, T.; Itoh, J.; Egashira, N.; Tokuda, Y.; Mori, K.; Osamura, Y.R. Overexpression of E2F-5 correlates with a pathological basal phenotype and a worse clinical outcome. Br. J. Cancer 2009, 100, 764-771.

124. Dahl, E.; En-Nia, A.; Wiesmann, F.; Krings, R.; Djudjaj, S.; Breuer, E.; Fuchs, T.; Wild, P.; Hartmann, A.; Dunn, S.; et al. Nuclear detection of Y-box protein-1 (YB-1) closely associates with progesterone receptor negativity and is a strong adverse survival factor in human breast cancer. BMC Cancer 2009, 9, 410-426.

125. Janz, M.; Harbeck, N.; Dettmar, P.; Berger, U.; Schmidt, A.; Jürchott, K.; Schmitt, M.; Royer, H.D. Y-box factor YB-1 predicts drug resistance and patient outcome in breast cancer independent of clinically relevant tumor biologic factors HER2, uPA and PAI-1. Int. J. Cancer 2002, 97, 278-282.

126. Wang, X.; Chao, L.; Li, X.; Ma, G.; Chen, L.; Zang, Y.; Zhou, G. Elevated expression of phosphorylated c-Jun NH2-terminal kinase in basal-like and "triple-negative" breast cancers. Human Pathol. 2010, 41, 401-406. 
127. Ribeiro-Silva, A.; Ramalho, L.N.Z.; Garcia, S.B.; Brandão, D.F.; Chahud, F.; Zucoloto, S. p63 correlates with both BRCA1 and cytokeratin 5 in invasive breast carcinomas: further evidence for the pathogenesis of the basal phenotype of breast cancer. Histopathology 2005, 47, 458-466.

128. Chae, B.J.; Bae, J.S.; Lee, A.; Park, W.C.; Seo, Y.J.; Song, B.J.; Kim, J.S.; Jung, S.S. p53 as a Specific Prognostic Factor in Triple-negative Breast Cancer. Jpn. J. Clin. Oncol. 2009, 39, 217-224.

129. Manie, E.; Vincent-Salomon, A.; Lehmann-Che, J.; Pierron, G.; Turpin, E.; Warcoin, M.; Gruel, N.; Lebigot, I.; Sastre-Garau, X.; Lidereau, R.; et al. High Frequency of TP53 Mutation in BRCA1 and Sporadic Basal-like Carcinomas but not in BRCA1 Luminal Breast Tumors. Cancer Res. 2009, 69, 663-671.

130. Foulkes, W.D.; Brunet, J.-S.; Stefansson, I. M.; Straume, O.; Chappuis, P.O.; Begin, L.R.; Hamel, N.; Goffin, J.R.; Wong, N.; Trudel, M.; et al. The Prognostic Implication of the BasalLike (Cyclin Ehigh/p27low/p53+/Glomeruloid-Microvascular-Proliferation+) Phenotype of BRCA1-Related Breast Cancer. Cancer Res. 2004, 64, 830-835.

131. Rakha, E.A.; Putti, T.C.; El-Rehim, D.M.A.; Paish, C.; Green, A.R.; Powe, D.G.; Lee, A.H.; Robertson, J.F.; Ellis, I.O. Morphological and immunophenotypic analysis of breast carcinomas with basal and myoepithelial differentiation. J. Pathol. 2006, 208, 495-506.

132. Yehiely, F.; Moyano, J.V.; Evans, J.R.; Nielsen, T.O.; Cryns, V.L. Deconstructing the molecular portrait of basal-like breast cancer. Trends Mol. Med. 2006, 12, 537-544.

133. Bolshakov, S.; Walker, C.M.; Strom, S.S.; Selvan, M.S.; Clayman, G.L.; El-Naggar, A.; Lippman, S.M.; Kripke, M.L.; Ananthaswamy, H.N. p53 Mutations in Human Aggressive and Nonaggressive Basal and Squamous Cell Carcinomas. Clin. Cancer Res. 2003, 9, 228-234.

134. Soussi, T. p53 alterations in human cancer: more questions than answers. Oncogene 2007, 26, 2145-2156.

135. Alsner, J.; Jensen, V.; Kyndi, M.; Vrou Offersen, B.; Vu, P.; Borresen-Dale, A.-L.; Overgaard, J. A comparison between p53 accumulation determined by immunohistochemistry and TP53 mutations as prognostic variables in tumours from breast cancer patients. Acta Oncol. 2008, 47, 600-607.

136. Chappuis, P.O.; Donato, E.; Goffin, J.R.; Wong, N.; Begin, L.R.; Kapusta, L.R.; Brunet, J.S.; Porter, P.; Foulkes, W.D. Cyclin E expression in breast cancer: predicting germline BRCA1 mutations, prognosis and response to treatment. Ann. Oncol. 2005, 16, 735-742.

137. Signoretti, S.; Di Marcotullio, L.; Richardson, A.; Ramaswamy, S.; Isaac, B.; Rue, M.; Monti, F.; Loda, M.; Pagano, M. Oncogenic role of the ubiquitin ligase subunit Skp2 in human breast cancer. J. Clin. Invest. 2002, 110, 633-641.

138. Voduc, D.; Nielsen, T.O.; Cheang, M.C.; Foulkes, W.D. The combination of high cyclin E and Skp2 expression in breast cancer is associated with a poor prognosis and the basal phenotype. Human Pathol. 2008, 39, 1431-1437.

139. Gauthier, M.L.; Berman, H.K.; Miller, C.; Kozakeiwicz, K.; Chew, K.; Moore, D.; Rabban, J.; Chen, Y.Y.; Kerlikowske, K.; Tlsty, T.D. Abrogated Response to Cellular Stress Identifies DCIS Associated with Subsequent Tumor Events and Defines Basal-like Breast Tumors. Cancer Cell 2007, 12, 479-491. 
140. Herschkowitz, J.; He, X.; Fan, C.; Perou, C. The functional loss of the retinoblastoma tumour suppressor is a common event in basal-like and luminal B breast carcinomas. Breast Cancer Res. 2008, 10, R75.

141. Subhawong, A.P.; Subhawong, T.; Nassar, H.; Kouprina, N.; Begum, S.; Vang, R.; Westra, W.H.; Argani, P. Most Basal-like Breast Carcinomas Demonstrate the Same Rb-/p16+ Immunophenotype as the HPV-related Poorly Differentiated Squamous Cell Carcinomas Which They Resemble Morphologically. Am. J. Surg. Pathol. 2009, 33, 163-175.

142. Yerushalmi, R.; Woods, R.; Ravdin, P.M.; Hayes, M.M.; Gelmon, K.A. Ki67 in breast cancer: prognostic and predictive potential. Lancet Oncol. 2010, 11, 174-183.

143. Livasy, C.A.; Perou, C.M.; Karaca, G.; Cowan, D.W.; Maia, D.; Jackson, S.; Tse, C.-K.; Nyante, S.; Millikan, R.C. Identification of a basal-like subtype of breast ductal carcinoma in situ. Human Pathol. 2007, 38, 197-204.

144. Wirapati, P.; Sotiriou, C.; Kunkel, S.; Farmer, P.; Pradervand, S.; Haibe-Kains, B.; Desmedt, C.; Ignatiadis, M.; Sengstag, T.; Schutz, F.; et al. Meta-analysis of gene expression profiles in breast cancer: toward a unified understanding of breast cancer subtyping and prognosis signatures. Breast Cancer Res. 2008, 10, R65.

145. Desmedt, C.; Haibe-Kains, B.; Wirapati, P.; Buyse, M.; Larsimont, D.; Bontempi, G.; Delorenzi, M.; Piccart, M.; Sotiriou, C. Biological Processes Associated with Breast Cancer Clinical Outcome Depend on the Molecular Subtypes. Clinical Cancer Res. 2008, 14, 5158-5165.

146. Ashworth, A. A Synthetic Lethal Therapeutic Approach: Poly(ADP) Ribose Polymerase Inhibitors for the Treatment of Cancers Deficient in DNA Double-Strand Break Repair. J. Clin. Oncol. 2008, 26, 3785-3790.

147. Foulkes, W.D.; Stefansson, I.M.; Chappuis, P.O.; Begin, L.R.; Goffin, J.R.; Wong, N.; Trudel, M.; Akslen, L.A. Germline BRCA1 Mutations and a Basal Epithelial Phenotype in Breast Cancer. J. Natl. Cancer Inst. 2003, 95, 1482-1485.

148. Silver, D.P.; Richardson, A.L.; Eklund, A.C.; Wang, Z.C.; Szallasi, Z.; Li, Q.; Juul, N.; Leong, C.-O.; Calogrias, D.; Buraimoh, A.; et al. Efficacy of Neoadjuvant Cisplatin in Triple-Negative Breast Cancer. J. Clin. Oncol. 2010, 28, 1145-1153.

149. Turner, N.C.; Reis-Filho, J.S.; Russell, A.M.; Springall, R.J.; Ryder, K.; Steele, D.; Savage, K.; Gillett, C.E.; Schmitt, F.C.; Ashworth, A.; et al. BRCA1 dysfunction in sporadic basal-like breast cancer. Oncogene 2006, 26, 2126-2132.

150. Gilbert, P.M.; Mouw, J.K.; Unger, M.A.; Lakins, J.N.; Gbegnon, M.K.; Clemmer, V.B.; Benezra, M.; Licht, J.D.; Boudreau, N.J.; Tsai, K.K.C.; et al. HOXA9 regulates BRCA1 expression to modulate human breast tumor phenotype. J. Clin. Invest. 2010, 120, 1535-1550.

151. Lacroix, M.; Leclercq, G. The "portrait" of hereditary breast cancer. Breast Cancer Res. Treat. 2005, 89, 297-304.

152. Lakhani, S.R.; O'Hare, M.J.; Ashworth, A. Profiling familial breast cancer. Nat. Med. 2001, 7, 408-410.

153. Hosey, A.M.; Gorski, J.J.; Murray, M. .; Quinn, J.E.; Chung, W.Y.; Stewart, G.E.; James, C.R.; Farragher, S.M.; Mulligan, J.M.; Scott, A.N.; et al. Molecular Basis for Estrogen Receptor \{alpha\} Deficiency in BRCA1-Linked Breast Cancer. J. Natl. Cancer Inst. 2007, 99, 1683-1694. 
154. Gorski, J.; James, C.; Quinn, J.; Stewart, G.; Staunton, K.; Buckley, N.; McDyer, F.; Kennedy, R.; Wilson, R.; Mullan, P.; et al. BRCA1 transcriptionally regulates genes associated with the basal-like phenotype in breast cancer. Breast Cancer Res. Treat. 2009, doi:10.1007/s10549-0090565-0.

155. Liu, X.; Holstege, H.; van der Gulden, H.; Treur-Mulder, M.; Zevenhoven, J.; Velds, A.; Kerkhoven, R.M.; van Vliet, M.H.; Wessels, L.F.A.; Peterse, J.L.; et al. Somatic loss of BRCA1 and p53 in mice induces mammary tumors with features of human BRCA1-mutated basal-like breast cancer. Proc. Natl. Acad. Sci. USA 2007, 104, 12111-12116.

156. McCarthy, A.; Savage, K.; Gabriel, A.; Naceur, C.; Reis-Filho, J.S.; Ashworth, A. A mouse model of basal-like breast carcinoma with metaplastic elements. J. Pathol. 2007, 211, 389-398.

157. Tan, A.R.; Swain, S.M. Therapeutic Strategies for Triple-Negative Breast Cancer. Cancer J. 2008, 14, 343-351.

158. Ashworth, A. A Synthetic Lethal Therapeutic Approach: Poly(ADP) Ribose Polymerase Inhibitors for the Treatment of Cancers Deficient in DNA Double-Strand Break Repair. J. Clin. Oncol. 2008, 26, 3785-3790.

159. Stebbing, J.; Ellis, P.; Tutt, A. PARP inhibitors in BRCA1-/BRCA2-associated and triplenegative breast cancers. Future Oncol. 2010, 6, 485-486.

160. Fong, P.C.; Boss, D.S.; Carden, C.P.; Roelvink, M.; De Greve, J.; Gourley, C.M.; Carmichael, J.; De Bono, J.S.; Schellens, J.H.M.; Kaye, S.B. AZD2281 (KU-0059436), a PARP (poly ADPribose polymerase) inhibitor with single agent anticancer activity in patients with BRCA deficient ovarian cancer: Results from a phase I study. Presented at the 2008 ASCO Annual Meeting, Boston, MA, USA, June 2008.

161. Yap, T.A.; Boss, D.S.; Fong, P.C.; Roelvink, M.; Tutt, A.; Carmichael, J.; O'connor, M.J.; Kaye, S.B.; Schellens, J.H.M.; de Bono, J.S. First in human phase I pharmacokinetic and pharmacodynamic study of KU-0059436 (Ku), a small molecule inhibitor of poly ADP-ribose polymerase (PARP) in cancer patients, including BRCA1/2 mutation carriers. Presented at the 2007 ASCO Annual Meeting, Chicago, IL, USA, June 2007.

162. Walter, O.; Prasad, M.; Lu, S.; Quinlan, R.M.; Edmiston, K.L.; Khan, A. IMP3 is a novel biomarker for triple negative invasive mammary carcinoma associated with a more aggressive phenotype. Human Pathol. 2009, 40, 1528-1533.

163. Nalwoga, H.; Arnes, J.B.; Wabinga, H.; Akslen, L.A. Expression of aldehyde dehydrogenase 1 (ALDH1) is associated with basal-like markers and features of aggressive tumours in African breast cancer. Br. J. Cancer 2010, 102, 369-375.

164. Resetkova, E.; Reis-Filho, J.; Jain, R.; Mehta, R.; Thorat, M.; Nakshatri, H.; Badve, S. Prognostic impact of ALDH1 in breast cancer: a story of stem cells and tumor microenvironment. Breast Cancer Res. Treat. 2009, doi: 10.1007/s10549-009-0619-3.

165. Otterbach, F.; Callies, R.; Adamzik, M.; Kimmig, R.; Siffert, W.; Schmid, K.; Bankfalvi, A. Aquaporin 1 (AQP1) expression is a novel characteristic feature of a particularly aggressive subgroup of basal-like breast carcinomas. Breast Cancer Res. Treat. 2009, 120, 67-76.

166. Arai, K.; Takano, S.; Teratani, T.; Ito, Y.; Yamada, T.; Nozawa, R. S100A8 and S100A9 Overexpression Is Associated with Poor Pathological Parameters in Invasive Ductal Carcinoma of the Breast. Curr. Cancer Drug Targets 2008, 8, 243-252. 
167. Arai, K.; Teratani, T.; Kuruto-Niwa, R.; Yamada, T.; Nozawa, R. S100A9 expression in invasive ductal carcinoma of the breast: S100A9 expression in adenocarcinoma is closely associated with poor tumour differentiation. Eur. J. Cancer 2004, 40, 1179-1187.

168. Skaland, I.; Janssen, E.A.M.; Gudlaugsson, E.; Hui Ru Guo, L.; Baak, J.P.A. The prognostic value of the proliferation marker Phosphohistone H3 (PPH3) in luminal, basal-like and triple negative phenotype invasive lymph node-negative breast cancer. Cell. Oncol. 2009, 31, 261-271.

169. Kuroda, H.; Ishida, F.; Nakai, M.; Ohnisi, K.; Itoyama, S. Basal cytokeratin expression in relation to biological factors in breast cancer. Human Pathol. 2008, 39, 1744-1750.

170. Lancashire, L.; Powe, D.; Reis-Filho, J.; Rakha, E.; Lemetre, C.; Weigelt, B.; Abdel-Fatah, T.; Green, A.; Mukta, R.; Blamey, R.; et al. A validated gene expression profile for detecting clinical outcome in breast cancer using artificial neural networks. Breast Cancer Res. Treat. 2009, 120, 83-93.

171. Tang, X.Y.; Umemura, S.; Tsukamoto, H.; Kumaki, N.; Tokuda, Y.; Osamura, R.Y. Overexpression of fatty acid binding protein-7 correlates with basal-like subtype of breast cancer. Pathol. Res. Prac. 2010, 206, 98-101.

172. Moyano, J.V.; Evans, J.R.; Chen, F.; Lu, M.; Werner, M.E.; Yehiely, F.; Diaz, L.K.; Turbin, D.; Karaca, G.; Wiley, E.; et al. alphaB-Crystallin is a novel oncoprotein that predicts poor clinical outcome in breast cancer. J. Clin. Invest. 2006, 116, 261-270.

173. Sitterding, S.M.; Wiseman, W.R.; Schiller, C.L.; Luan, C.; Chen, F.; Moyano, J.V.; Watkin, W.G.; Wiley, E.L.; Cryns, V.L.; Diaz, L.K. alphaB-crystallin: A novel marker of invasive basallike and metaplastic breast carcinomas. Ann. Diagn. Pathol. 2008, 12, 33-40.

174. Pal, S.; Childs, B.; Pegram, M. Emergence of nonanthracycline regimens in the adjuvant treatment of breast cancer. Breast Cancer Res. Treat. 2010, 119, 25-32.

175. Choi, W.W.L.; Weisenburger, D.D.; Greiner, T.C.; Piris, M.A.; Banham, A.H.; Delabie, J.; Braziel, R.M.; Geng, H.; Iqbal, J.; Lenz, G.; et al. A New Immunostain Algorithm Classifies Diffuse Large B-Cell Lymphoma into Molecular Subtypes with High Accuracy. Clin. Cancer Res. 2009, 15, 5494-5502.

176. Geiss, G.K.; Bumgarner, R.E.; Birditt, B.; Dahl, T.; Dowidar, N.; Dunaway, D.L.; Fell, H.P.; Ferree, S.; George, R.D.; Grogan, T.; et al. Direct multiplexed measurement of gene expression with color-coded probe pairs. Nat. Biotech. 2008, 26, 317-325.

177. Paik, S.; Shak, S.; Tang, G.; Kim, C.; Baker, J.; Cronin, M.; Baehner, F.L.; Walker, M.G.; Watson, D.; Park, T.; et al. A Multigene Assay to Predict Recurrence of Tamoxifen-Treated, Node-Negative Breast Cancer. N. Engl. J. Med. 2004, 351, 2817-2826.

178. Rimsza, L.M.; LeBlanc, M.L.; Unger, J.M.; Miller, T.P.; Grogan, T.M.; Persky, D.O.; Martel, R.R.; Sabalos, C.M.; Seligmann, B.; Braziel, R.M.; et al. Gene expression predicts overall survival in paraffin-embedded tissues of diffuse large B-cell lymphoma treated with R-CHOP. Blood 2008, 112, 3425-3433.

179. Sotiriou, C.; Pusztai, L. Gene-Expression Signatures in Breast Cancer. N. Engl. J. Med. 2009, 360, 790-800. 
180. Schneider, B.P.; Winer, E.P.; Foulkes, W.D.; Garber, J.; Perou, C.M.; Richardson, A.; Sledge, G.W.; Carey, L.A. Triple-Negative Breast Cancer: Risk Factors to Potential Targets. Clin. Cancer Res. 2008, 14, 8010-8018.

(C) 2010 by the authors; licensee MDPI, Basel, Switzerland. This article is an Open Access article distributed under the terms and conditions of the Creative Commons Attribution license (http://creativecommons.org/licenses/by/3.0/). 